\title{
Drug Targeting of a Peptide Radiopharmaceutical through the Primate Blood-Brain Barrier In Vivo with a Monoclonal Antibody to the Human Insulin Receptor
}

\author{
Dafang Wu, Jing Yang, and William M. Pardridge \\ Department of Medicine, UCLA School of Medicine, Los Angeles, California 90095-1682
}

\begin{abstract}
Peptide radiopharmaceuticals are potential imaging agents for brain disorders, should these agents be enabled to undergo transport through the blood-brain barrier (BBB) in vivo. Radiolabeled $A \beta^{1-40}$ images brain amyloid in tissue sections of Alzheimer's disease autopsy brain, but this peptide radiopharmaceutical cannot be used to image brain amyloid in vivo owing to negligible transport through the BBB. In these studies, ${ }^{125} \mathrm{I}-\mathrm{A} \beta^{1-40}$ was monobiotinylated (bio) and conjugated to a BBB drug delivery and brain targeting system comprised of a complex of the 83-14 monoclonal antibody (mAb) to the human insulin receptor, which is tagged with streptavidin (SA). A marked increase in rhesus monkey brain uptake of the ${ }^{125}$ I-bio- $A \beta^{1-40}$ was observed after conjugation to the 8314-SA delivery system at $3 \mathrm{~h}$ after intravenous injection. In contrast, no measurable brain uptake of ${ }^{125} \mathrm{I}$-bio-A $\beta^{1-40}$ was observed in the absence of a BBB drug delivery system. The peptide radiopharmaceutical was degraded in brain with export of the iodide radioactivity, and by $48 \mathrm{~h}$ after intravenous injection, $90 \%$ of the radioactivity was cleared from the brain. In conclusion, these studies describe a methodology for BBB drug delivery and brain targeting of peptide radiopharmaceuticals that could be used for imaging amyloid or other brain disorders. (J. Clin. Invest. 1997. 100:1804-1812.) Key words: Alzheimer's disease • amyloid $\bullet$ monoclonal antibody $\bullet$ insulin receptor $\cdot$ avidin
\end{abstract}

\section{Introduction}

Peptide radiopharmaceuticals have potential for diagnostic imaging (1). The somatostatin receptor is overexpressed in certain neuroendocrine tumors, as well as brain tumors such as meningiomas or gliomas, and ${ }^{125} \mathrm{I}$ - or ${ }^{111}$ In-labeled octreotide, a somatostatin peptide analog, has been used to image these tumors $(2,3)$. Owing to the small size of the peptide radiopharmaceutical, octreotide readily crosses the porous capillaries perfusing tumors in the periphery, or certain brain tumors such

Address correspondence to William M. Pardridge, M.D., Department of Medicine, UCLA School of Medicine, Los Angeles, CA 900951682. Phone: 310-825-8858; FAX: 310-206-5163; E-mail: wpardrid@ med1.medsch.ucla.edu

Received for publication 30 April 1997 and accepted in revised form 7 August 1997.

J. Clin. Invest.

(C) The American Society for Clinical Investigation, Inc. 0021-9738/97/10/1804/09 \$2.00

Volume 100, Number 7, October 1997, 1804-1812

http://www.jci.org as meningiomas, which lack a blood-brain barrier (BBB). 1 However, well-differentiated gliomas, which also overexpress somatostatin receptors, have an intact $\mathrm{BBB}$; it is not possible to image these tumors with octreotide $(3,4)$, since this peptide does not cross the BBB in vivo (5).

In addition to tumors, it should also be possible to image other medical disorders with peptide radiopharmaceuticals, such as amyloid. The deposition of amyloid in brain of Alzheimer's disease correlates with the degree of dementia in this disorder $(6,7)$. Extracellular amyloid in Alzheimer's disease is comprised of two types: senile (neuritic) plaque and vascular amyloid (8-12). Both types of amyloid in Alzheimer's disease are comprised of a 43-amino acid amyloidotic peptide, designated $A \beta^{1-43}$. There are as well $A \beta^{1-42}$ forms, produced from the abnormal proteolysis of a normal cellular protein, the amyloid peptide precursor (13).

The A $\beta$ amyloid of tissue sections of Alzheimer's disease autopsy brain can be identified with dyes such as Congo Red, or with antibodies directed against certain epitopes of the $\mathrm{A} \beta^{1-42 / 43}$ peptide (14). However, the $A \beta$ amyloid of brain sections may also be identified in vitro by autoradiography with ${ }^{125} \mathrm{I}-\mathrm{A} \beta^{1-40}$, a peptide containing the first 40 amino acids of the $\mathrm{A} \beta^{1-42 / 43}$ peptide that deposits with high affinity onto preexisting $A \beta$ amyloid (15). Therefore, radiolabeled $A \beta^{1-40}$ is a potential peptide radiopharmaceutical that could be used for neurodiagnostic quantitation of the $A \beta$ amyloid burden in Alzheimer's disease brain of living subjects using standard external detection methodologies, such as single photon emission computed tomography or positron emission tomography. However, ${ }^{125} \mathrm{I}-\mathrm{A} \beta^{1-40}$ does not cross the BBB in rats unless a vector-mediated $\mathrm{BBB}$ drug delivery system is used (16). A $\beta$ amyloid does not deposit in the brain of aged rats, but does form in the brain of New World primates, such as the aged (15-20 yr) squirrel monkey, as vascular amyloid, and is produced in the brain of Old World primates, such as the aged (27-30 yr) rhesus monkey, in neuritic plaque form (17-20).

These studies use ${ }^{125} \mathrm{I}-\mathrm{A} \beta^{1-40}$ adapted to a BBB drug delivery system that enables the peptide to enter the brain from blood to a high degree, allowing for imaging of the distribution of the peptide radiopharmaceutical in the brain after systemic (intravenous, i.v.) injection. The goal of these studies is fourfold: first, to prepare radiolabeled peptide pharmaceutical conjugated to the $\mathrm{BBB}$ delivery system; second, to demonstrate that the deposition of ${ }^{125} \mathrm{I}-\mathrm{A} \beta^{1-40}$ on amyloid plaques in sec-

1. Abbreviations used in this paper: $\mathrm{A} \beta^{1-40}$, first 40 amino acids of $\beta$-peptide of Alzheimer's disease; AUC, area under the plasma concentration curve; BBB, blood-brain barrier; bio, biotinylated; HILC, hydrophilic interaction liquid chromatography; HIR, human insulin receptor; OX26, murine mAb to rat transferrin receptor; PS, permeability-surface area product; RHB, Ringer-Hepes buffer; SA, streptavidin; TEAP, triethylamine phosphate; $\mathrm{V}_{\mathrm{D}}$, volume of distribution. 
tions of Alzheimer's disease autopsy brain is not impaired after conjugation to the BBB delivery system; third, to administer the peptide radiopharmaceutical to young rhesus monkeys in order to measure the degree to which the brain uptake of the peptide radiopharmaceutical is enhanced by the use of the BBB drug targeting system; and fourth, to measure brain uptake of the peptide radiopharmaceutical in the brain at various times $(3,24$, and $48 \mathrm{~h})$ after i.v. injection in order to determine the approximate half-life of the radioactivity in the brain. The last is a measure of the biotransformation of the peptide radiopharmaceutical in the living brain after initial penetration through the BBB.

The BBB delivery system used in these studies is the 83-14 $\mathrm{mAb}$ to the human insulin receptor (HIR). The 83-14 HIR $\mathrm{mAb}$ undergoes receptor-mediated transcytosis through the $\mathrm{BBB}$ of Old World primates such rhesus monkeys, but not New World primates such as squirrel monkeys (21). This observation is consistent with the greater genetic similarity between humans and Old World primates compared with New World primates (22). The 83-14 HIR mAb has a very high affinity for the human or Old World primate insulin receptor and is both an endocytosing antibody in isolated human brain capillaries and a BBB-transcytosing antibody in anesthetized rhesus monkeys (21). The conjugation of ${ }^{125} \mathrm{I}-\mathrm{A} \beta^{1-40}$ to the 8314 HIR mAb is facilitated by the use of avidin-biotin technology applied to brain drug delivery (23). In this approach, the peptide radiopharmaceutical is monobiotinylated and, in parallel, a conjugate of streptavidin (SA) and the 83-14 HIR mAb is prepared through the formation of stable thio-ether linkage between the SA and the 83-14 mAb (16). The use of avidinbiotin technology applied to drug delivery takes advantage of the extremely high affinity of biotin binding $\left(K_{\mathrm{D}}=10^{-15} \mathrm{M}\right.$; dissociation $t_{1 / 2}=89 \mathrm{~d}$ ) by either avidin or SA. SA is used in lieu of avidin in these studies. Owing to the cationic nature of avidin as opposed to SA, which is slightly acidic, the plasma pharmacokinetics of the $\mathrm{mAb} / \mathrm{SA}$ analog is optimized compared with the relatively rapid plasma clearance of $\mathrm{mAb} / \mathrm{avi}$ din conjugates (23).

\section{Methods}

Materials. Four male adult rhesus monkeys (Macaca mulatta) weighing 8.2-10.5 (9.45 \pm 1.02$) \mathrm{kg}$ were purchased form the National Institutes of Health (Bethesda, MD) and the University of Michigan Medical School (Ann Arbor, MI). Snap-frozen human autopsy Alzheimer's disease brain, used for preparation of frozen sections, and fresh control autopsy human brain (obtained 24-32 h postmortem), used for the isolation of microvessels, were provided by Prof. Harry Vinters (UCLA Department of Pathology/Neuropatholgy). Human $A \beta^{1-40}$ was purchased from Bachem, Inc. (Torrance, CA). Biotinylated $A \beta^{1-40}$ (bio- $\mathrm{A} \beta^{1-40}$ ), which is monobiotinylated at the amino terminus, was obtained from Quality Controlled Biochemicals, Inc. (Hopkinton, MA). Immobilized iminobiotin gel, Traut's reagent, and $m$-maleimidobenzoyl $N$-hydroxysuccinimide ester were obtained from Pierce Chemical Co. (Rockford, IL). Cartridges of polyhydroxyethyl aspartamide were obtained from PolyLC, Inc. (Columbia, MD). Iodine- 125 was purchased from Amersham Corp. (Arlington Heights, IL). Chloramine T was from MCB Reagents (Cincinnati, OH). TSK-GEL ${ }^{\circledR}$ G2000SW $_{\mathrm{XL}}$ HPLC gel filtration column $(7.8 \times 300 \mathrm{~mm})$ was obtained from TosoHaas (Montgomeryville, PA). Recombinant SA and all other reagents were obtained from Sigma Chemical Co. (St. Louis, MO).

Synthesis and purification of $m A b$ 8314/SA conjugate. The 83-14 hybridoma (24) was provided by Prof. Kenneth Siddle (Cambridge University, UK). The 83-14 mAb was purified from mouse ascites using protein G-Sepharose 4 Fast Flow affinity chromatography as described previously (21). The purified 83-14 mAb was thiolated with a 10:1 molar ratio of Traut's reagent (25), and Ellman's reagent was used to demonstrate that this reaction inserted a single thiol group on
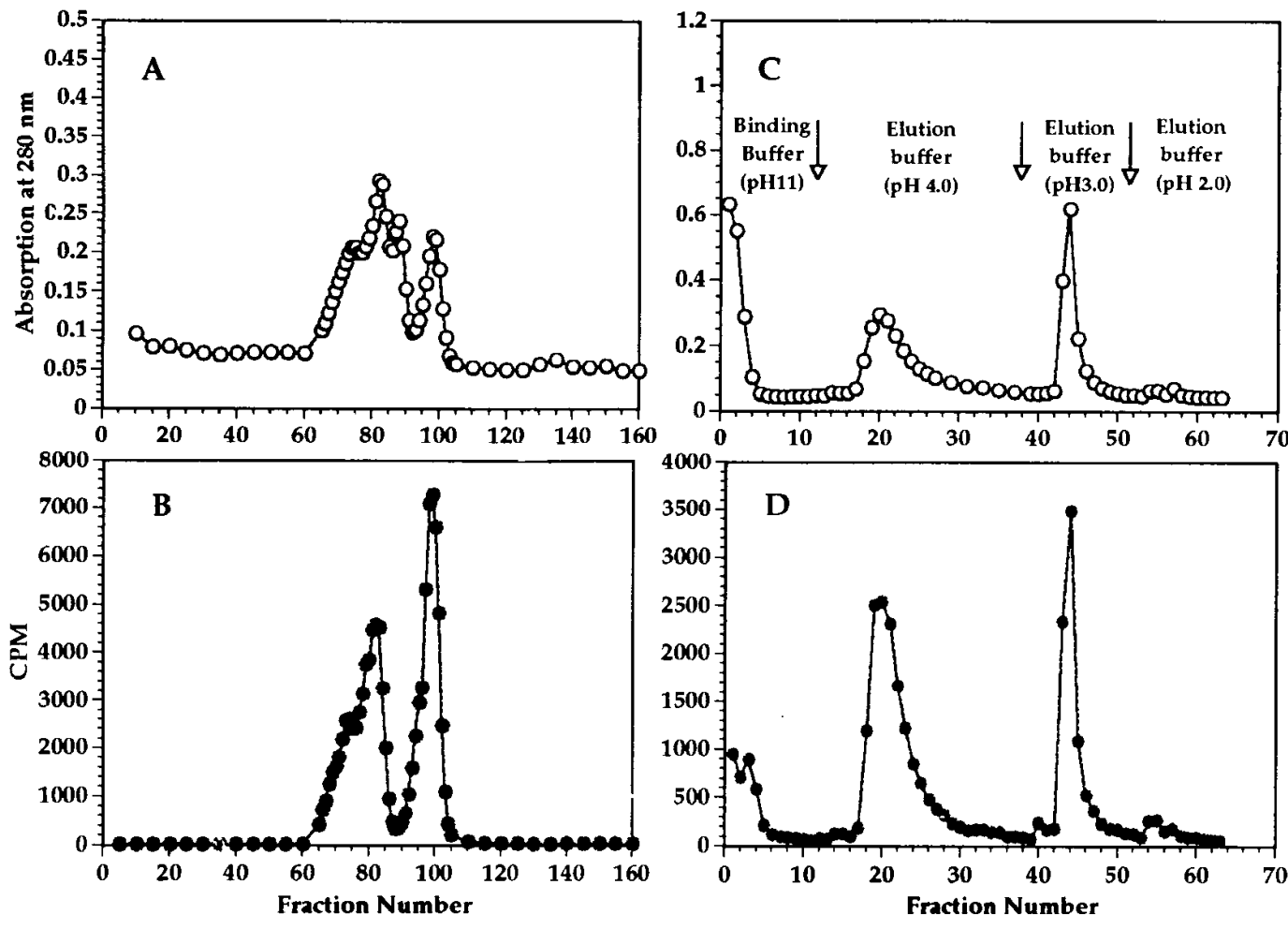

Figure 1. Gel filtration ( $A$ and $B$ ) and immobilized iminobiotin affinity ( $C$ and $D$ ) chromatography of mAb 8314-SA conjugate. The fraction size of the gel filtration was $3 \mathrm{ml}$, and the fraction size in the affinity chromatography was $0.5 \mathrm{ml}$. 
the surface of the mAb (26). The SA was activated with a 20:1 molar ratio of $m$-maleimidobenzol $N$-hydroxysuccinimide ester (27), and the thiolated 83-14 mAb and activated SA were incubated overnight at room temperature. After addition of $2 \mu \mathrm{Ci}$ of ${ }^{3} \mathrm{H}$-biotin as a tracer, the sample was loaded on to a $2.6 \times 92-\mathrm{cm}$ column of Sephacryl S-300 HR (Pharmacia Biotech, Piscataway, NJ) and eluted with $0.01 \mathrm{M}$ $\mathrm{Na}_{2} \mathrm{HPO}_{4} / 0.15 \mathrm{M} \mathrm{NaCl} / 0.05 \%$ Tween-20, $\mathrm{pH} 7.4$, at $30 \mathrm{ml} / \mathrm{h}$ for $16 \mathrm{~h}$. Fractions $(3 \mathrm{ml})$ were collected and measured for $\mathrm{A}_{280}$ and ${ }^{3} \mathrm{H}$ radioactivity, allowing for separation of the 8314-SA conjugate from the unconjugated SA, which eluted at a larger volume of the column (Fig. 1, $A$ and $B)$.

The 8314-SA $\mathrm{A}_{280}$ peak (Fig. $1 A$ ) was greater than the 8314-SA ${ }^{3} \mathrm{H}$-biotin binding peak (Fig. $1 B$ ), which indicated that unconjugated 83-14 $\mathrm{mAb}$ was also contained in this peak. Owing to the very high affinity $\left(K_{\mathrm{D}}=0.45 \mathrm{nM}\right)$ of the 83-14 mAb for the BBB HIR (21), unconjugated 83-14 mAb could compete for binding to the BBB of the 8314-SA conjugate. Therefore, unconjugated $83-14 \mathrm{mAb}$ was removed by iminobiotin affinity chromatography. The fractions from the Sephacryl S-300 column were concentrated with a Centricon-30 (Amicon, Inc., Beverly, MA). The iminobiotin gel $(2 \mathrm{ml})$ was packed in a column $(7 \times 100 \mathrm{~mm})$, and the column was activated with $10 \mathrm{ml}$ of binding buffer $(50 \mathrm{mM}$ ammonium carbonate/0.5 M NaCl, $\mathrm{pH}$ 11.0). The 8314-SA conjugate was applied to the column followed by incubation at room temperature for $30 \mathrm{~min}$, and then eluted with elution buffer $(50 \mathrm{mM}$ ammonium carbonate/ $0.5 \mathrm{M} \mathrm{NaCl})$ of $\mathrm{pH} 4.0,3.0$, and 2.0, respectively. Only the fraction eluting at $\mathrm{pH} 4.0$ was used in subsequent studies. Fractions $(0.8 \mathrm{ml})$ were collected and measured for $\mathrm{A}_{280}$ and ${ }^{3} \mathrm{H}$ radioactivity (Fig. 1, $C$ and $D$ ). The number of biotinbinding sites on the 8314-SA conjugate was measured with a ${ }^{3} \mathrm{H}$-biotin binding assay as described previously (28), and was found to be $4.0 \pm 0.2$, consistent with a $1: 1$ conjugation of the $83-14 \mathrm{mAb}$ and SA, which has four biotin-binding sites.

Iodination of bio- $A \beta^{1-40}$ and hydrophilic interaction chromatography $(H I L C)$. Bio-A $\beta^{1-40}(10 \mu \mathrm{g}, 2.1 \mathrm{nmol})$ was iodinated with Iodine-125 $(2 \mathrm{mCi}, 1.0 \mathrm{nmol})$ and chloramine $\mathrm{T}(39 \mathrm{nmol})$ at room temperature for $2 \mathrm{~min}$ (16). After addition of $125 \mathrm{nmol}$ of sodium metabisulfite to quench the iodination, the reaction solution was diluted with $1 \mathrm{ml}$ of $90 \%$ acetonitrile $/ 10 \% 20 \mathrm{mM}$ TEAP (trimethylamine/phosphoric acid), $\mathrm{pH} 2.8$, and loaded onto the polyhydroxyethyl aspartamide extraction cartridge, which was preactivated with $5 \mathrm{ml}$ of $90 \%$ acetonitrile/10\% $20 \mathrm{mM}$ TEAP. The ${ }^{125}$ I-bio-A $\beta^{1-40}$ was eluted with $3 \mathrm{ml}$ of the same buffer, followed by a series of acetonitrile/TEAP buffers with decreasing percent acetonitrile (Fig. 2). The ${ }^{125}$ I-bio-A $\beta^{1-40}$ eluted at $50 \%$ acetonitrile (Fig. 2), and these fractions were pooled and evaporated to $200 \mu$ l. The iodinated bio-A $\beta^{1-40}$ had a TCA precipita-

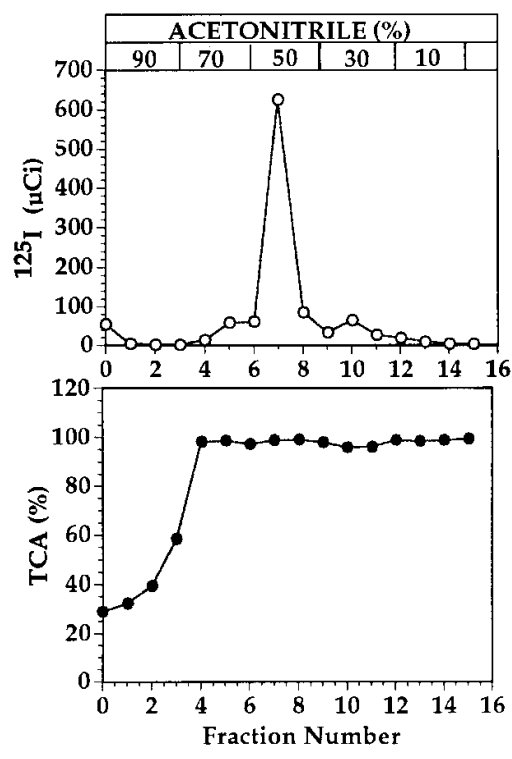

Figure 2. HILC elution (top) and TCA precipitability percentage (bottom) of bio-A $\beta^{1-40}$ after radiolabeling with Iodine-125. The fraction size was $1 \mathrm{ml}$. The percentage of acetonitrile for each step elution is shown.

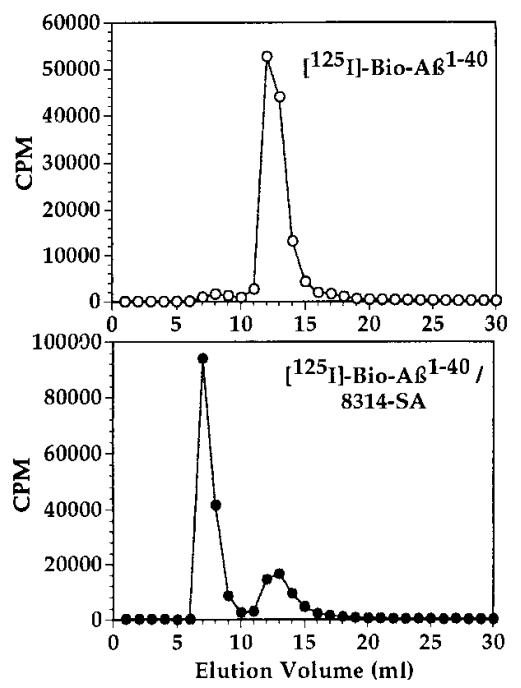

Figure 3. Gel filtration HPLC profile of ${ }^{125}$ I-bio$\mathrm{A} \beta^{1-40}$ (top) and ${ }^{125}$ I-bio$\mathrm{A} \beta^{1-40} / 8314-\mathrm{SA}$ conjugate (bottom). The salt volume of the gel filtration HPLC column was $14.3 \mathrm{ml}$, the elution volume of ${ }^{125}$ I-bio-A $\beta^{1-40}$ was $12 \mathrm{ml}$, and that of ${ }^{125}$ I-bio-A $\beta^{1-40} / 8314-S A$ was $6 \mathrm{ml}$.

tion $>97 \%$ (Fig. 2), and was injected into the rhesus monkeys on the same day as iodination.

Gel filtration HPLC. The conjugation of ${ }^{125} \mathrm{I}$-bio-A $\beta^{1-40}$ to 8314 SA was demonstrated by gel filtration HPLC using the TSK-GEL

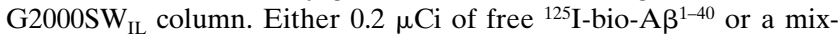
ture of $0.2 \mu \mathrm{Ci}$ of ${ }^{125}$ I-bio-A $\beta^{1-40}(1 \mathrm{pmol})$ and $2 \mu \mathrm{g}$ of $8314-\mathrm{SA}(10$ pmol) was applied to the column, which was eluted with a buffer containing $0.1 \mathrm{M} \mathrm{Na}_{2} \mathrm{HPO}_{4} / 0.15 \mathrm{M} \mathrm{NaCl} / 0.05 \%$ Tween-20, $\mathrm{pH} 7.0$, at 0.5 $\mathrm{ml} / \mathrm{min}$ for $60 \mathrm{~min}$. Fractions $(1 \mathrm{ml})$ were collected and measured for Iodine-125 radioactivity. The ${ }^{125} \mathrm{I}$-bio- $\mathrm{A} \beta^{1-40}$ eluted at $12 \mathrm{ml}$, and $>90 \%$ of the radioactivity shifted to an elution volume of $6-7 \mathrm{ml}$ when the 8314-SA conjugate was added (Fig. 3), indicating that $>90 \%$ of the ${ }^{125} \mathrm{I}-\mathrm{A} \beta^{1-40}$ was biotinylated and captured by the $8314-\mathrm{SA}$ conjugate.

Capillary binding studies. Human brain capillaries were isolated and cryopreserved as reported previously (29). The isolated capillaries were thawed at room temperature and resuspended in RingerHepes buffer (RHB, pH 7.4) containing $141 \mathrm{mM} \mathrm{NaCl}, 4 \mathrm{mM} \mathrm{KCl}$, $2.8 \mathrm{mM} \mathrm{CaCl}_{2}, 10 \mathrm{mM}$ Hepes, and $0.1 \%$ HSA. The capillaries (100$125 \mu \mathrm{g}$ protein) were incubated with $0.025 \mu \mathrm{Ci} / \mathrm{ml}$ of either ${ }^{3} \mathrm{H}$-biotin or ${ }^{125} \mathrm{I}$-bio-A $\beta^{1-40}$ either in the presence or absence of $0.5 \mathrm{nM} 8314-\mathrm{SA}$. Some of the tubes were enriched with $10 \mu \mathrm{g} / \mathrm{ml}$ of either unconjugated 83-14 mAb or mouse $\mathrm{IgG}_{2 \mathrm{a}}$ for competition studies. The reaction volume was brought to $0.5 \mathrm{ml}$ with the $\mathrm{RHB} / 0.1 \% \mathrm{HSA}$. The incubations were performed at room temperature for 15,30 , and 60 $\min (29)$.

Emulsion autoradiography. Snap-frozen Alzheimer's disease cortex was provided by the UCLA Department of Pathology/Neuropathology, and $15-\mu$ sections were cut on a Bright cryostat and thawmounted to gelatin-coated slides. The slides were warmed to room temperature, air-dried, and incubated for $30 \mathrm{~min}$ with TBM buffer (0.05 M Tris- $\mathrm{HCl}, 0.1 \%$ BSA, $\left.10 \mathrm{mM} \mathrm{MnCl}_{2}, \mathrm{pH} 7.4\right)$. The slides were incubated with $250 \mu \mathrm{l}$ of TBM buffer containing $0.5 \mu \mathrm{Ci} / \mathrm{ml}$ of either ${ }^{125}$ I-bio-A $\beta^{1-40}$ or ${ }^{125}$ I-bio-A $\beta^{1-40} / 8314-S A$ with or without $10 \mu \mathrm{M}$ unlabeled $A \beta^{1-40}$ for competition. The slides were incubated at room temperature for $2 \mathrm{~h}$, washed four times with 2-min washes in $0.05 \mathrm{M}$ Tris- $\mathrm{HCl}\left(\mathrm{pH} \mathrm{7.4)}\right.$ at $4^{\circ} \mathrm{C}$ followed by two 5 -s washes in $\mathrm{H}_{2} \mathrm{O}$ at $4^{\circ} \mathrm{C}$, and air-dried. These slides were dipped with emulsion (NTB2; Eastman Kodak Co., Rochester, NY) in the darkroom for $5 \mathrm{~s}$ followed by air-drying at room temperature for $30 \mathrm{~min}$, and then put in a box and exposed at $-20^{\circ} \mathrm{C}$ in the dark. For development, the slides were removed from the freezer, thawed at room temperature for $30 \mathrm{~min}$, then fixed in $2.5 \%$ paraformaldehyde in $\mathrm{PBS}$ at $10^{\circ} \mathrm{C}$ for $30 \mathrm{~s}$. After a PBS wash, the slides were developed (developer D19; Eastman Kodak Co.) for $2 \mathrm{~min}$, washed in water, counterstained with methyl green-pyronine, and examined by bright field microscopy (16). 
Pharmacokinetics and brain drug delivery. After overnight fasting, the rhesus monkeys were sedated with an intramuscular (i.m.) dose of ketamine $(10 \mathrm{mg} / \mathrm{kg})$, followed by anesthesia with $1.5 \%$ halothane. A 1.0-ml volume of buffered saline ( $\mathrm{pH} 7.4)$ containing $300 \mu \mathrm{Ci}$ $(32 \mu \mathrm{Ci} / \mathrm{kg})$ of either unconjugated ${ }^{125} \mathrm{I}$-bio-A $\beta^{1-40}$ or ${ }^{125} \mathrm{I}$-bio-A $\beta^{1-40}$ coupled to $60 \mu \mathrm{g}$ of the 8314-SA vector was injected i.v., and blood samples were collected at $0.25,2.5,5,15,30,60,120$, and $180 \mathrm{~min}$ postdose for monkeys 1 (18 yr) and 2 (26 yr). The two monkeys were killed by a lethal injection of sodium pentobarbital $(100 \mathrm{mg} / \mathrm{kg})$, and their brains were removed instantly, cut into 5 coronal slabs, frozen in powdered dry ice, and stored at $-70^{\circ} \mathrm{C}$ for subsequent frozen sectioning and phosphorimaging. Gray and white matter of the frontal cortex were separated, and radioactivity was counted using a gamma counter (Beckman Instruments, Inc., Fullerton, CA). For the time course study, the conjugate of ${ }^{125}$ I-bio-A $\beta^{1-40}(300 \mu \mathrm{Ci})$ and 8314-SA $(60 \mu \mathrm{g})$ was injected i.v. into monkeys 3 and 4 (both $15 \mathrm{yr})$ after sedation with $10 \mathrm{mg} / \mathrm{kg}$ ketamine i.m. Monkey 3 was killed $24 \mathrm{~h}$ postdose, and monkey $448 \mathrm{~h}$ postdose, for removal of the brain.

Pharmacokinetic parameters were calculated by fitting the plasma radioactivity data of monkeys 1 and 2 to a biexponential equation:

$A(t)=A_{1} e^{-k_{1} t}+A_{2} e^{-k_{2} t}$

where $A(t)=$ percent ID per milliliter plasma. The biexponential equation was fit to TCA-precipitable plasma radioactivity data using a derivative-free nonlinear regression analysis (PARBMDP, Biomedical Computer P-Series, developed at UCLA Health Sciences Computing Facilities). The data were weighted using weight $=1 /(\text { concentration })^{2}$, where concentration $=$ percent ID per milliliter plasma. The brain volume of distribution $\left(\mathrm{V}_{\mathrm{D}}\right)$ and the $\mathrm{BBB}$ permeability-surface area (PS) product of ${ }^{125} \mathrm{I}$-bio-A $\beta^{1-40}$ after i.v. injection, and the pharmacokinetic parameters such as plasma clearance, initial plasma volume, systemic volume of distribution, and steady state area under the plasma concentration curve $\left(\mathrm{A} \mathrm{U} \mathrm{Cl}{ }_{0}^{\infty}\right)$ were determined from $\mathrm{A}_{1}, \mathrm{~A}_{2}$, $\mathrm{k}_{1}$, and $\mathrm{k}_{2}$, as described previously (21).

PhosphorImager analysis. After the monkey was killed, the brain was rapidly removed from the cranium and sectioned into 5 coronal slabs of $\sim 4 \mathrm{~mm}$. Each slab was plunged individually into powdered dry ice for rapid freezing over $30 \mathrm{~min}$. Embedding medium was placed between the brain slab and circular slabs of laboratory cork (35-mm diameter, 1/8-inch thickness), and this was placed back in the powdered dry ice for additional freezing over a 2-h period. These preparations were then stored at $-70^{\circ} \mathrm{C}$ in $35-\mathrm{mm}$ petri dishes. For frozen sectioning, the brain was thawed to $-20^{\circ} \mathrm{C}$, the cork was mounted on a cryostat orientable object holder with additional embedding medium and placed on a universal holder, and $20-\mu \mathrm{m}$ sections were cut on a Bright cryostat at $-20^{\circ} \mathrm{C}$. Sections were mounted on precleaned microscope slides $(75 \times 50 \times 1 \mathrm{~mm}$; Fisher Scientific Co., Pittsburgh, PA) and air-dried at room temperature for $60 \mathrm{~min}$. The slides were then glued to a paper grid, which was wrapped in transparent film, and placed in a large cassette with a $35 \times 43-\mathrm{cm}$ PhosphorImager screen (Molecular Dynamics, Sunnyvale, CA). The cassette was developed at room temperature for $45 \mathrm{~d}$, and the screen was read using a PhosphorImager scanner (Molecular Dynamics) under high resolution mode. The images were transferred electronically as a TIFF file with Fetch-FTP for Macintosh 2.1.2. (Dartmouth College, Hanover, NH) to the laboratory Power Macintosh 7100/66 microcomputer, and were opened as PICT files in Adobe Photoshop, colorized with NIH Image software, and prints were obtained with a digital printer (Fujix Pictrography 3000; Fuji Photo Film Co., Tokyo, Japan).

\section{Results}

The affinity of the 83-14 mAb for the human brain insulin receptor was unaffected by conjugation of the 50,000-D SA to the antibody, as demonstrated by the radioreceptor data shown in

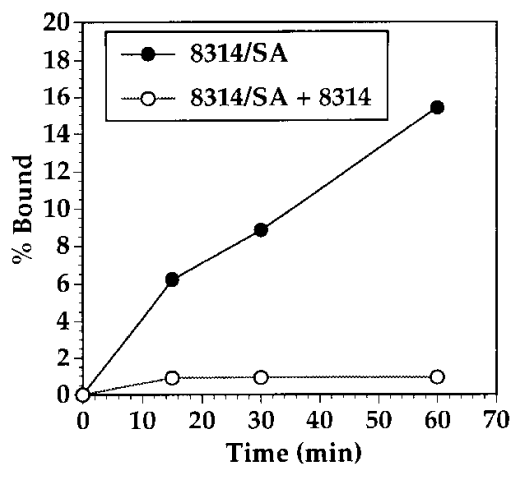

Figure 4. Time course of $0.5 \mathrm{nM}$ 8314-SA binding to human brain capillary preparation in the absence (filled circles) or presence (open circles) of $10 \mu \mathrm{g} / \mathrm{ml} 8314$ $\mathrm{mAb}$. The tracer used in this radioreceptor assay was ${ }^{3} \mathrm{H}$-biotin $(1 \mathrm{nM})$, which binds to the 8314-SA conjugate with a high affinity. No competition of ${ }^{3} \mathrm{H}$ -

biotin/8314-SA conjugate uptake by the capillaries was observed with $10 \mu \mathrm{g} / \mathrm{ml}$ mouse $\operatorname{IgG}_{2 \mathrm{a}}$, the isotype control for the 83-14 mAb. The capillary uptake of ${ }^{3} \mathrm{H}$-biotin bound to $\mathrm{SA}$ alone was $<2 \%$. Data are means of duplicates that varied $<10 \%$.

Fig. 4. In this study, ${ }^{3} \mathrm{H}$-biotin was bound to the 8314-SA conjugate and incubated with human brain capillaries with or without $10 \mu \mathrm{g} / \mathrm{ml}$ unconjugated $83-14 \mathrm{mAb}$. The binding of the ${ }^{3} \mathrm{H}$-biotin/8314-SA to isolated human brain capillaries reached $16 \%$ at $60 \mathrm{~min}$ of incubation at room temperature (Fig. 4), which is comparable with the binding to human brain capillaries of unconjugated ${ }^{125}$ I-labeled $83-14 \mathrm{mAb}$ (21). Next, we tested the binding of ${ }^{125} \mathrm{I}-\mathrm{bio}-\mathrm{A} \beta^{1-40}$ to human brain capillaries in the presence of either no vector or the 8314-SA vector, with or without $10 \mu \mathrm{g} / \mathrm{ml}$ unconjugated $83-14 \mathrm{mAb}$ (Fig. 5). These studies showed avid binding of the ${ }^{125}$ I-bio- $\mathrm{A} \beta^{1-40} / 8314$-SA conjugate to the human brain capillaries that was suppressed to the background level by the inclusion of $10 \mu \mathrm{g} / \mathrm{ml}$ unconjugated $83-14 \mathrm{mAb}$ (Fig. 5). This background level is defined by the capillary uptake of ${ }^{125}$ I-bio-A $\beta^{1-40}$ without any antibody added (plot designated as control in Fig. 5). The binding of the ${ }^{125}$ I-bio-A $\beta^{1-40} / 8314-\mathrm{SA}$ conjugate to the neuritic plaques of tissue sections of autopsy Alzheimer's disease brain is demonstrated in the emulsion autoradiography studies shown in Fig. 6. In these experiments, ${ }^{125}$ I-bio-A $\beta^{1-40}$ was applied to tissue sections either in the absence or presence of 8314-SA conjugate. When ${ }^{125} \mathrm{I}$-bio-A $\mathrm{A}{ }^{1-40}$ was applied to tissue sections in the form of the conjugate, it was preincubated for $45 \mathrm{~min}$ at room temperature with the 8314-SA conjugated before application to the Alzheimer's disease brain tissue sections. Binding of ${ }^{125} \mathrm{I}-\mathrm{A} \beta^{1-40}$ either alone or in the presence of 8314-SA conjugate to the neuritic plaques of Alzheimer's disease sections was abolished by coincubation with $10 \mu \mathrm{M}$ unlabeled $\mathrm{A} \beta^{1-40}$.

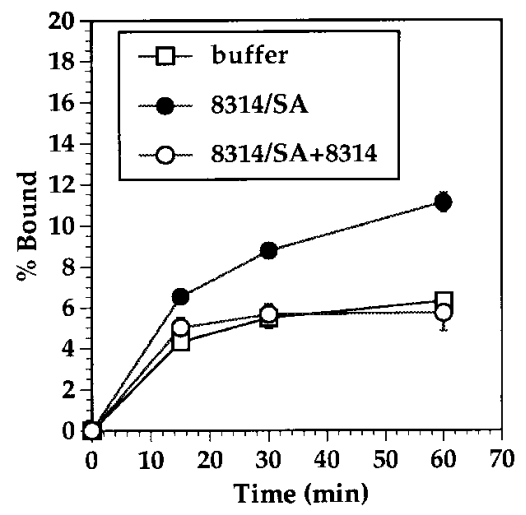

Figure 5. Time course of ${ }^{125}$ I-bio- $A \beta^{1-40}(0.23$ $\mathrm{nM}$ ) binding to human brain capillary preparation in the presence of buffer, $0.5 \mathrm{nM} 8314-$ SA, or $0.5 \mathrm{nM} 8314-\mathrm{SA}$ plus $10 \mu \mathrm{g} / \mathrm{ml}$ unconjugated $8314 \mathrm{mAb}$. Data are mean $\pm \operatorname{SE}(n=3)$. 

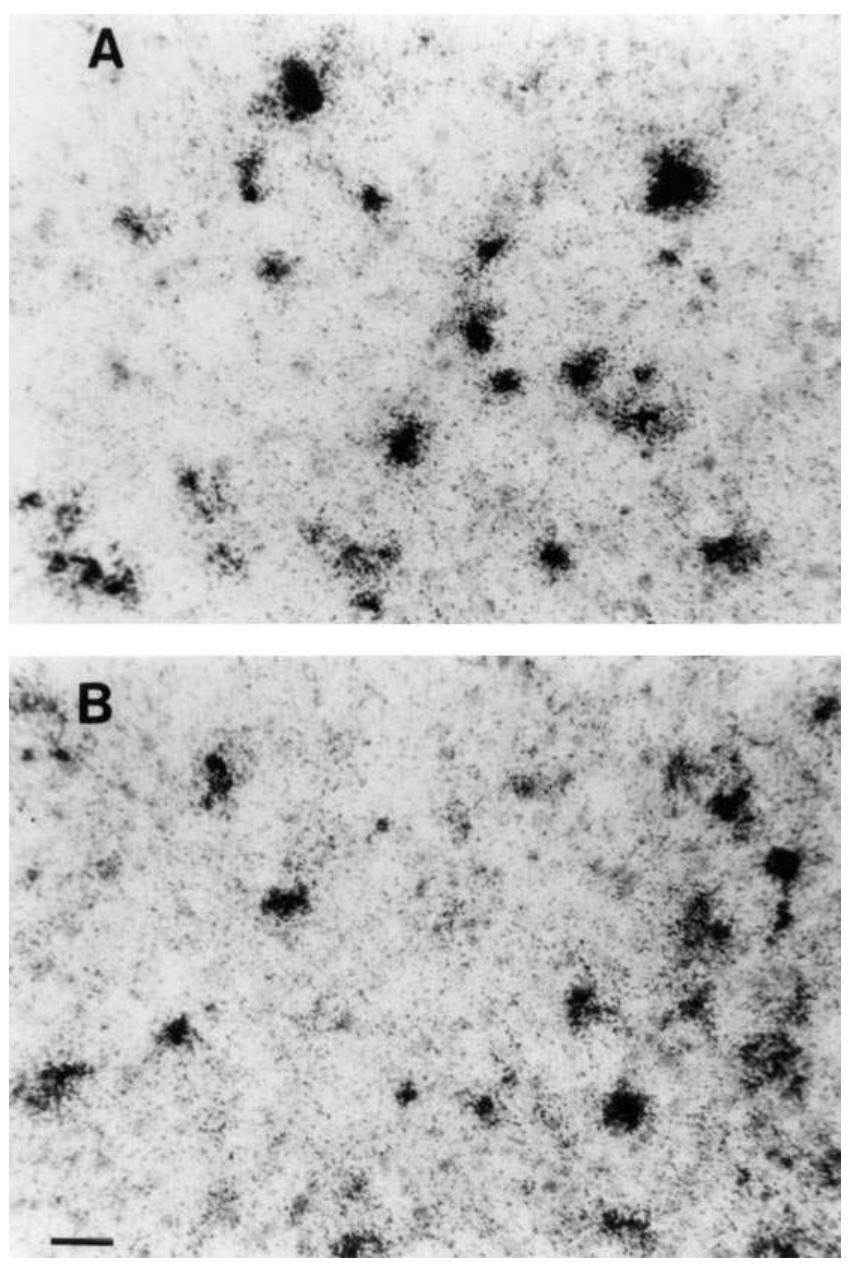

Figure 6. Emulsion autoradiography showing the binding of ${ }^{125}$ I-bio$\mathrm{A} \beta^{1-40}(A)$ or ${ }^{125}$ I-bio-A $\beta^{1-40} / 8314-\mathrm{SA}$ conjugate $(B)$ to amyloid plaques of frozen sections of human Alzheimer's disease brain under bright field microscopy. Magnification bar is $23 \mu \mathrm{m}$.

${ }^{125}$ I-bio-A $\beta^{1-40}$ was removed rapidly from plasma after i.v. injection in the rhesus monkey (Fig. 7). This rate of removal was further enhanced by attachment of the peptide to the 8314-SA conjugate (Fig. 7). The peptide was relatively metabolically labile, as the percentage of plasma radioactivity pre-
Table I. Pharmacokinetic Parameters for ${ }^{125} I-$ bio- $A \beta^{1-40}$ and ${ }^{125}$ I-bio-A $\beta^{1-40} / 8314-S A$ Conjugate after an i.v. Dose

\begin{tabular}{lcc}
\hline \multicolumn{1}{c}{ Parameter } & ${ }^{125}$ I-bio-A $\beta^{1-40}$ & ${ }^{125}$ I-bio-A $\beta^{1-40} / 8314-\mathrm{SA}$ \\
\hline $\mathrm{A}_{1}(\% \mathrm{ID} / \mathrm{ml})$ & 0.137 & 0.150 \\
$\mathrm{~A}_{2}(\% \mathrm{ID} / \mathrm{ml})$ & 0.0502 & 0.0183 \\
$\mathrm{k}_{1}\left(\mathrm{~min}^{-1}\right)$ & 0.206 & 0.0948 \\
$\mathrm{k}_{2}\left(\mathrm{~min}^{-1}\right)$ & 0.00649 & 0.00635 \\
$t_{1 / 2}{ }^{1}(\mathrm{~min})$ & 3.37 & 7.31 \\
$t_{1 / 2}{ }^{2}(\mathrm{~min})$ & 107 & 109 \\
$\left.A U C\right|_{0} ^{180^{\circ}}(\% \mathrm{ID} \mathrm{min} / \mathrm{ml})$ & 6.00 & 3.54 \\
$\left.A U C\right|_{0} ^{\infty}(\% \mathrm{ID} \mathrm{min} / \mathrm{ml})$ & 8.40 & 4.45 \\
$\mathrm{~V}_{\mathrm{C}}(\mathrm{ml} / \mathrm{kg})$ & 65.0 & 68.5 \\
$\mathrm{~V}_{\mathrm{SS}}(\mathrm{ml} / \mathrm{kg})$ & 207 & 272 \\
$\mathrm{Cl}(\mathrm{ml} / \mathrm{min} / \mathrm{kg})$ & 1.45 & 2.59 \\
& &
\end{tabular}

Parameters derived from the data in Fig. 7. $\mathrm{V}_{\mathrm{C}}, \mathrm{V}_{\mathrm{SS}}$, and $\mathrm{Cl}$ refer to kilogram body weight. $A_{n}$ and $k_{n}$ refer to intercepts and slopes of the biexponential curve fit to the plasma data in Fig. 7. The $t_{1 / 2}{ }^{\mathrm{n}}$ were calculated from $\mathrm{k}_{\mathrm{n}} . V_{c}, V_{S S}$, and $C l$ are plasma central volume, whole body volume of distribution, and systemic clearance, respectively.

cipitable by TCA was decreased to 40 and $25 \%$ at $180 \mathrm{~min}$ after administration of either unconjugated ${ }^{125}$ I-bio-A $\beta^{1-40}$ or ${ }^{125}$ I-bio-A $\beta^{1-40} / 8314-S A$, respectively (Fig. 7). The brain TCAprecipitable radioactivity at $3 \mathrm{~h}$ after injection of ${ }^{125}$ I-bio$\mathrm{A} \beta^{1-40} / 8314-\mathrm{SA}$ conjugate, $82.8 \pm 0.9 \%$, was much higher than the corresponding TCA-precipitable radioactivity in serum at this time point, $26.3 \pm 0.6 \%$. The plasma TCA-precipitable radioactivity data was subjected to biexponential analysis (see Methods) to compute the pharmacokinetic parameters shown in Table I. The frontal cortex was counted for total Iodine-125 radioactivity, and $V_{D}$ was computed for $A \beta^{1-40}$ with or without conjugation to 8314-SA vector (Table I). The gray matter BBB PS for the free peptide or for the conjugate was computed from brain $\mathrm{V}_{\mathrm{D}}$ and AUC (see Methods), and was $<0.25$ and $1.74 \mu \mathrm{l} / \mathrm{min} \cdot \mathrm{g}$, respectively. The brain $\mathrm{V}_{\mathrm{D}}$ of bio- $\mathrm{A} \beta^{1-40}$ conjugated to the 8314-SA delivery system was more than 10 -fold greater than the brain $V_{D}$ of the unconjugated peptide (Table I). This difference is seen also in the images obtained with the PhosphorImager (Fig. 8). There is no discernible brain uptake when the peptide was administered without the brain delivery system (Fig. 8, left). However, when the peptide pharmaceuti-
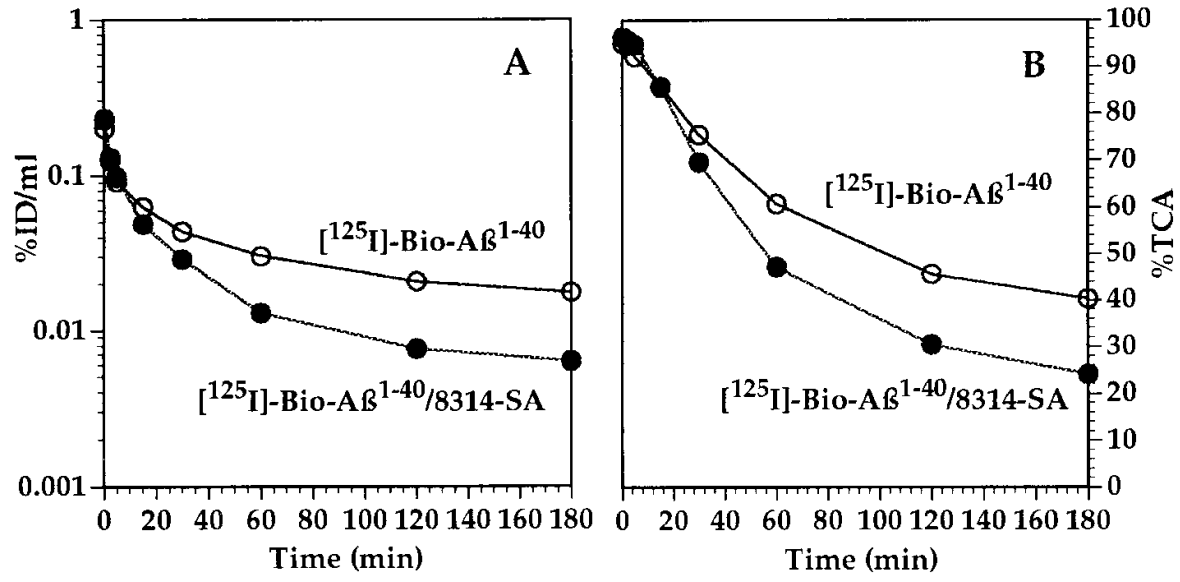

Figure 7. (A) Plasma profile of either unconjugated ${ }^{125} \mathrm{I}$-bio-A $\beta^{1-40}$ (open circles) or ${ }^{125}$ I-bio-A $\beta^{1-40} / 8314$-SA conjugate (filled circles) after an i.v. dose of $30 \mu \mathrm{Ci}$ per monkey. (B) Time course of the percentage of plasma radioactivity precipitable with TCA after the i.v. injection. 


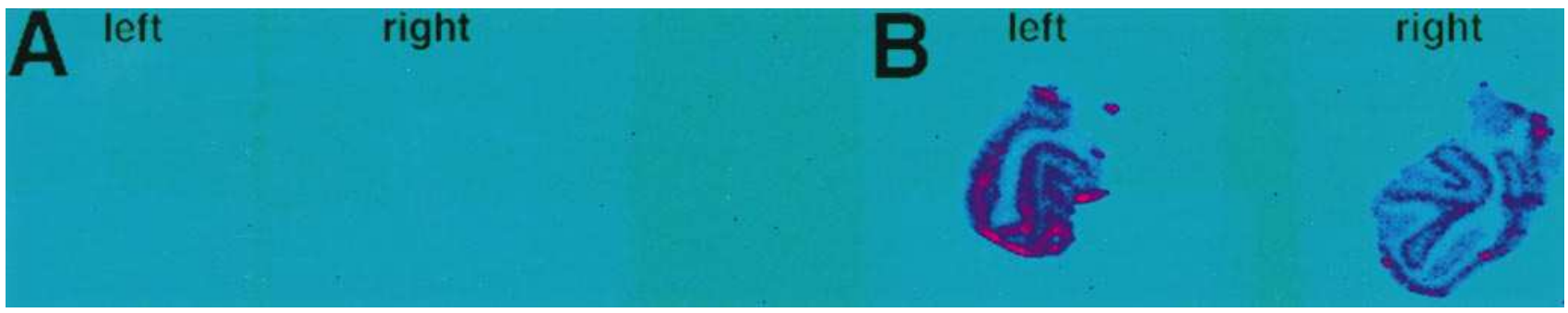

Figure 8. PhosphorImager scans for left or right cerebral hemisphere in two different rhesus monkeys. $(A)$ Brain uptake $3 \mathrm{~h}$ after i.v. injection of $300 \mu \mathrm{Ci}$ of unconjugated ${ }^{125} \mathrm{I}$-bio-A $\beta^{1-40}$. (B) Brain uptake $3 \mathrm{~h}$ after i.v. injection of ${ }^{125}$ I-bio-A $\beta^{1-40}$ conjugated to $8314-S A$. Images for the left and right occipital lobes are shown.

cal was administered conjugated to the BBB delivery system, there was robust uptake of the peptide radiopharmaceutical (Fig. 8, right), and the differential uptake between white and gray matter tracts is clearly illuminated with the PhosphorImager analysis (Fig. 8). The peptide radiopharmaceutical conjugated to the 8314-SA delivery system was also injected into rhesus monkeys sacrificed at 24 and $48 \mathrm{~h}$ after administration in order to determine the rate of decline of brain radioactivity after administration of the peptide radiopharmaceutical conjugated to the BBB delivery system. The brain $V_{D}$ in either white or gray matter at 3, 24, and $48 \mathrm{~h}$ are shown in Fig. 9, and the brain images at 3,24, $48 \mathrm{~h}$ after administration of the peptide radiopharmaceutical conjugated to the $\mathrm{BBB}$ delivery system are shown in Fig. 10. These studies indicate that nearly $90 \%$ of the brain radioactivity is cleared by $48 \mathrm{~h}$ after i.v. administration. Plotting the brain $V_{D}$ (Fig. 9) on a semi-log plot versus time (hours) indicates that the $t_{1 / 2}$ of brain radioactivity is $16.0 \mathrm{~h}(r=0.99)$.

\section{Discussion}

The results of these studies are consistent with the following conclusions. First, a peptide radiopharmaceutical may be specially formulated for BBB drug delivery, and this formulation requires $(a)$ synthesis and purification of the 8314-SA conjugate (Fig. 1) and $(b)$ synthesis and purification of radiolabeled monobiotinylated $A \beta^{1-40}$ using HILC (Fig. 2). Second, the bifunctionality of the 8314-SA conjugate is retained, as this molecule binds both ${ }^{125}$ I-bio-A $\beta^{1-40}$ (Fig. 3) and the human brain capillary or BBB insulin receptor (Figs. 4 and 5). Third, the biologic activity of the ${ }^{125}$ I-bio-A $\beta^{1-40}$ peptide radiopharmaceutical is retained despite conjugation to the 8314-SA vector, as the complex still binds the neuritic plaques in sections of Alzheimer's disease brain to a degree comparable to that of the unconjugated bio-A $\beta^{1-40}$ (Fig. 6). Fourth, the pharmacokinetics of the peptide radiopharmaceutical (Fig. 7 and Table I) demonstrate a relatively rapid decline in the plasma concentration and metabolic stability of the conjugate. Finally, the brain uptake of the peptide radiopharmaceutical without conjugation to the BBB delivery system is negligible (Figs. 8 and 9), but the brain uptake of the peptide radiopharmaceutical conjugated to the 8314-SA BBB delivery system is very high (Figs. 8 and 9). This brain uptake of radioactivity is nearly $90 \%$ cleared by $48 \mathrm{~h}$ after i.v. injection (Figs. 8 and 10).

Sephacryl S-300 gel filtration (Fig. 1) removes unconjugated SA, and iminobiotin affinity chromatography (Fig. 2) removes unconjugated 83-14 mAb. Use of iminobiotin affinity chromatography is a novel procedure that allows for elution of the 8314-SA conjugate from the iminobiotin column under relatively mild conditions. It is important to remove all unconjugated 83-14 mAb, because the affinity of this antibody for BBB insulin receptor is extremely high, with a $K_{\mathrm{D}}$ of $0.45 \pm 0.10 \mathrm{nM}$

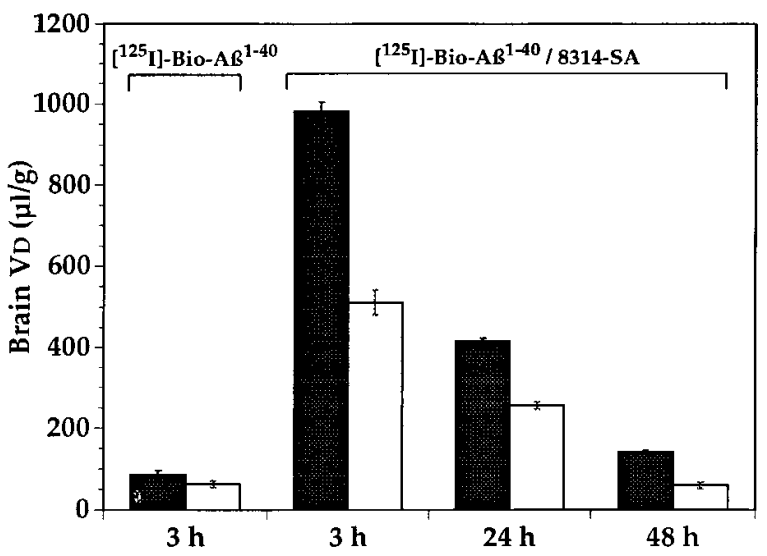

Figure 9. Brain $\mathrm{V}_{\mathrm{D}}$ of either ${ }^{125} \mathrm{I}$-bio- $\mathrm{A} \beta^{1-40}$ or ${ }^{125} \mathrm{I}$-bio- $\mathrm{A} \beta^{1-40} / 8314$ SA conjugate at 3,24 , or $48 \mathrm{~h}$ after i.v. injection to rhesus monkeys. Filled bars, $\mathrm{V}_{\mathrm{D}}$ values of gray matter of the monkey brains. Open bars, $\mathrm{V}_{\mathrm{D}}$ values of white matter. Data are mean $\pm \mathrm{SE}(n=3)$.

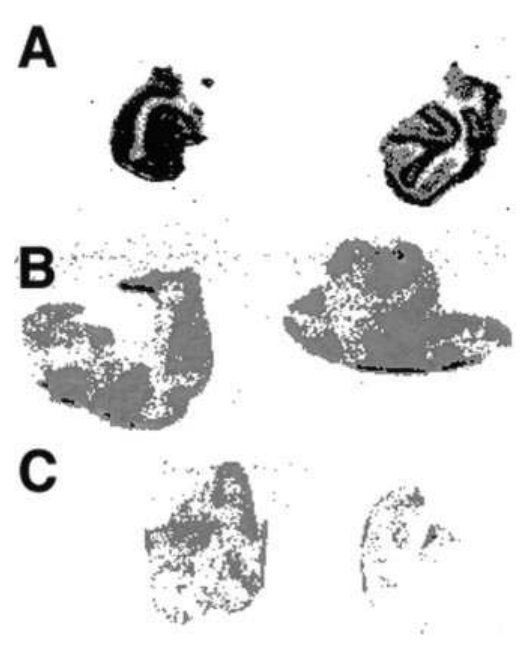

Figure 10. PhosphorImages representing the brain uptake of ${ }^{125}$ I-bio-A $\beta^{1-40}$ conjugated to the 8314-SA delivery system at $3(A)$, $24(B)$, and $48 \mathrm{~h}(C)$ after i.v. injection of $300 \mu \mathrm{Ci}$ per rhesus monkey. Three different monkeys were used for these studies, one each for the measurements at 3,24, and $48 \mathrm{~h}$, respectively. Left column, Brain uptake in the left occipital lobe. Right column, Brain uptake in the right occipital lobe. 
(21). Therefore, the presence of any unconjugated 83-14 mAb in the formulation comprised of the 8314-SA complex would compete with binding of 8314-SA conjugate to BBB insulin receptor, and this would inhibit brain uptake of the conjugated peptide radiopharmaceutical. In parallel to the production of $8314-\mathrm{SA}$ conjugate, bio-A $\beta^{1-40}$ must be iodinated and purified. $\mathrm{A} \beta^{1-40}$ is a relatively hydrophobic peptide, and subsequent biotinylation and iodination further increases the hydrophobicity of this molecule, which makes it difficult to release ${ }^{125} \mathrm{I}-$ bio-A $\beta^{1-40}$ from reverse phase surfaces (our unpublished observations). However, this problem is obviated and the percent recovery of ${ }^{125}$ I-bio-A $\beta^{1-40}$ after iodination is high using HILC (Fig. 2). Similar results were demonstrated previously after monobiotinylation and iodination of a vasoactive intestinal peptide analog (30).

The multifunctionality of the amyloid imaging agent is retained after attachment of ${ }^{125}$ I-bio-A $\beta^{1-40}$ to the 8314 -SA conjugate. The three domains are depicted in Fig. 11, and include the amyloid-binding domain, a linker domain, and a BBB transport domain. The $\mathrm{mAb}$ and avidin domains are joined by a thiol-ether linkage (-S- in Fig. 11), a much more stable bond than the disulfide $(-S-S$-) linkage used in previous formulations (30). In this case (Fig. 11), the peptide is attached to the targeting vector by a noncleavable bond that confers metabolic stability and is used because $A \beta^{1-40}$ still binds to the target amyloid despite attachment to the delivery system (Fig. 6). High affinity binding of ${ }^{125}$ I-bio-A $\beta^{1-40} / 8314-S A$ to the BBB insulin receptor is demonstrated both in vitro with isolated brain capillaries (Figs. 4 and 5) and in vivo in rhesus monkeys (Fig. 8). The avid binding in vivo is consistent with previous studies showing that endogenous insulin exerts minimal inhibition of 83-14 mAb binding to the $\mathrm{BBB}$ insulin receptor (21). The biotin-binding property of the 8314-SA conjugate is contained within the linker domain (Fig. 11), and is demonstrated with HPLC experiments in Fig. 3 and radioreceptor assays in Figs. 4 and 5. The amyloid-binding domain is comprised of radiolabeled $A \beta^{1-40}$, and the retention of the amyloid-binding properties of the peptide pharmaceutical after conjugation to the $\mathrm{BBB}$ delivery system is demonstrated with the emulsion autoradiography experiments using Alzheimer's disease tissue sections (Fig. 6). These results are similar to previously reported emulsion and film autoradiography experiments demonstrating binding of ${ }^{125} \mathrm{I}$-bio- $\mathrm{A} \beta^{1-40}$ to amyloid plaques of sections of Alzheimer's disease brain after conjugation of the peptide pharmaceutical to a conjugate of SA and the OX26 mAb (16), which is a murine mAb to the rat transferrin receptor (31). In these previous experiments, the biotin linkage was attached to the $\epsilon$-amino group of an internal lysine residue (16). In contrast, these experiments use an $A \beta^{1-40}$ analog in which the biotin moiety is attached to the amino terminus. Previous investigations have demonstrated that attachment of biotin to the amino terminus of $A \beta^{1-40}$ does not impair deposition of this peptide onto preexisting $A \beta$ amyloid plaques (32).

Pharmacokinetic studies demonstrate that ${ }^{125} \mathrm{I}$-bio- $\mathrm{A} \beta^{1-40}$ is removed rapidly from the bloodstream and is subjected to rapid metabolic degradation, as indicated by the decrease in plasma TCA precipitability (Fig. 6). Although ${ }^{125} \mathrm{I}-\mathrm{A} \beta^{1-40}$ is $>90 \%$ bound by human albumin (33), this binding is relatively weak in vivo and does not inhibit the rapid clearance of ${ }^{125}$ I-bio-A $\beta^{1-40}$ in vivo (Fig. 7). The TCA-soluble Iodine-125 radioactivity in plasma at $1-3 \mathrm{~h}$ after i.v. injection of the peptide may arise from proteolysis of the peptide with release of iodo-

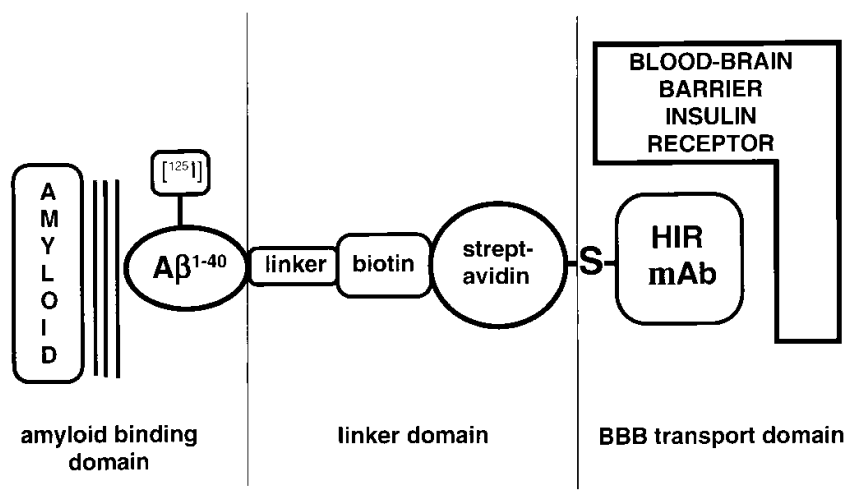

Figure 11. Scheme depicting the multifunctionality and three domains of the peptide radiopharmaceutical conjugated to the BBB delivery system. The imaging agent is comprised of amyloid-binding domain, a linker domain, and a BBB transport domain, the last constituted by the mAb to the HIR. The HIR is localized in human brain capillary endothelium (reference 21), which forms the BBB in vivo.

tyrosine. An alternative pathway is surface deiodination of the intact peptide, possibly by ectoenzymes on the endothelial surface of organ capillary beds. Evidence for this pathway is the observation that the systemic clearance $(\mathrm{C} 1$, Table I) for the ${ }^{125} \mathrm{I}$-bio-A $\beta^{1-40} / \mathrm{OX} 26-\mathrm{SA}$ conjugate, $2.6 \mathrm{ml} / \mathrm{min} / \mathrm{kg}$, is approximately fourfold greater than the systemic clearance of the unconjugated ${ }^{125} \mathrm{I}-83-14 \mathrm{mAb}$ in rhesus monkeys, $0.39-1.00 \mathrm{ml} /$ $\mathrm{min} / \mathrm{kg}(21)$. The rapid conversion of plasma radioactivity into TCA-soluble metabolites shown in Fig. 7 indicates that radioiodination may not be the optimal formulation for peptide radiopharmaceuticals used in the future, and that alternative radiolabeling procedures might be considered. For example, chelating agents may be attached to $\epsilon$-amino groups of internal lysines of the $A \beta^{1-40}$ peptide, which would allow for radiolabeling with Indium-111 or Technetium-99m (34).

Despite the relatively rapid rate of plasma clearance of conjugated bio-A $\beta^{1-40}$ from plasma (Fig. 7) and the relative reduction in plasma AUC (Table I), there is still robust brain uptake of peptide radiopharmaceutical after attachment to 8314-SA conjugate (Figs. 8 and 9). There is a twofold greater enrichment in brain uptake of bio-A $\beta^{1-40}$ conjugated to 8314-SA vector in gray matter versus white matter (Figs. 8 and 9), consistent with previous observations showing a greater abundance of insulin receptor in gray matter versus white matter (21). This greater abundance of receptor is due to the approximately three- to fourfold greater vascular density in gray matter versus white matter, as demonstrated in previous morphometric studies in rhesus monkey brain (21).

There is no measurable brain uptake of unconjugated bio$\mathrm{A} \beta^{1-40}$ by the brain (Figs. 8 and 9 ), consistent with previous studies in rats indicating lack of significant transport of $A \beta^{1-40}$ through the BBB in vivo (16). Earlier experiments reported a brain $V_{D}$ of unconjugated $A \beta^{1-40}$ after internal carotid artery perfusion that exceeded the brain plasma volume measured with labeled sucrose $(16,35)$. However, these results are consistent with nonspecific absorption of $A \beta^{1-40}$ to the brain vasculature (16). The nonspecific absorption of ${ }^{125} \mathrm{I}-\mathrm{bio}-\mathrm{A} \beta^{1-40}$ is further demonstrated with isolated brain capillaries in vitro, as shown by the experiments in Fig. 5, where the brain capillary 
binding of ${ }^{125}$ I-bio-A $\beta^{1-40}$ without vector (plot designated as buffer in Fig. 5) is much greater than the nonspecific binding of ${ }^{3} \mathrm{H}$-biotin/8314-SA in the presence of $10 \mu \mathrm{g} / \mathrm{ml} 83-14 \mathrm{mAb}$ (Fig. 4). The absorption of $A \beta^{1-40}$ to meningeal vascular surfaces has also been demonstrated in vivo in the rat (36). The nonspecific absorption of $A \beta^{1-40}$ to the luminal surface of the brain capillary endothelium after in vivo administration would not allow for imaging brain amyloid in Alzheimer's disease. This amyloid is on the brain side of the microvasculature and is separated from labeled $A \beta^{1-40}$ absorbed to the luminal surface of the brain capillary endothelium by the endothelial membranes that constitute the $\mathrm{BBB}$ in vivo. Since $\mathrm{A} \beta^{1-40}$ does not cross the $B B B$, systemically infused ${ }^{125} I-A \beta^{1-40}$ cannot lable the $\mathrm{A} \beta$ amyloid in the brain unless there is BBB disruption. However, the BBB is intact in Alzheimer's disease (37). Recent studies performed common carotid arterial infusion of relatively high doses $(80-165 \mu \mathrm{Ci} / \mathrm{kg})$ of ${ }^{125} \mathrm{I}-\mathrm{A} \beta^{1-40}$ into aged anesthetized squirrel monkeys (38). However, the only vessels labeled in this report appear to be meningeal vessels in brain, which are extracerebral vessels that lack a BBB.

The avid brain uptake of the peptide pharmaceutical formulated as a conjugate with the BBB delivery system (Fig. 8) demonstrates that brain structures can be imaged readily with this approach, as the quality of the image is comparable to a standard 2-deoxyglucose image seen with PET scans in humans or quantitative autoradiography in rats. The clear image of peptide radiopharmaceutical distribution in the brain (Fig. 8 ) is due to the high activity of the $83-14 \mathrm{mAb}$ as a BBB delivery sector. The PS product of BBB transport of 83-14 mAb in the primate brain, $5.4 \mu \mathrm{l} / \mathrm{min} / \mathrm{g}$ (21), is nearly 10 -fold greater than the PS product of BBB transport of an antitransferrin receptor $\mathrm{mAb}$ in the primate brain (39). The image in Fig. 8 demonstrates that it is possible to achieve a high distribution of a peptide radiopharmaceutical in the brain using a BBB delivery system, whereas there is negligible brain uptake of the peptide radiopharmaceutical when no BBB delivery system is used. The time course studies in Fig. 10 indicate that nearly $90 \%$ of the peptide radiopharmaceutical initially extracted by the brain is subject to metabolic transformation and clearance from the brain by $48 \mathrm{~h}$ after i.v. administration. However, it is anticipated that the 48-h signal in subjects with $\mathrm{A} \beta$ amyloid will be increased considerably above the background level shown in Fig. 10 for subjects that have no brain amyloid. This is because once the peptide radiopharmaceutical traverses the $\mathrm{BBB}$, the imaging agent will come in contact with extracellular amyloid, and soluble $A \beta^{1-40}$ deposits immediately on the surface of preexisting $A \beta$ amyloid plaque (40). The $A \beta$ plaque may constitute up to $15 \%$ of the brain volume in Alzheimer's disease (41). This deposition will effectively increase organ residence time of radioactivity in the brain. In the absence of extracellular amyloid, the imaging agent will undergo receptor-mediated endocytosis into cells in brain-bearing insulin receptor on the cell membrane surface; this endocytosis is followed by degradation within the lysosomal compartment and release of iodide radioactivity (Fig. 10). However, susceptibility of $A \beta^{1-40}$ to protease attack is greatly reduced after deposition onto preexisting $A \beta$ amyloid (42).

The formulation of the amyloid imaging agent described in Fig. 11 may appear to be relatively complex from the point of view of manufacturing this agent as an amyloid imaging agent for use in human subjects suspected of having Alzheimer's disease. However, the formulation of the amyloid imaging agent is simplified with the use of avidin-biotin technology, and the use of a two-vial formulation. One vial contains the mAb/avidin fusion protein, and the second contains the radiolabeled, biotinylated $A \beta^{1-40}$ peptide. The two vials may be mixed immediately before administration to the subject, which takes advantage of the rapid capture of biotin analogs by $\mathrm{mAb} /$ avidin fusion proteins. Recently, an $\mathrm{mAb} /$ avidin fusion gene and fusion protein have been synthesized and expressed, and demonstrated to have optimal pharmacokinetics (43). The immunogenicity of the mAb portion of the delivery vector may be minimized by humanization of the murine framework sequences of the mAb (44). The immunogenicity of the avidin component may be minimized owing to oral antigen tolerance (45) induced by the presence of egg products in the diet. Indeed, relatively large $(10 \mathrm{mg})$ quantities of avidin have been administered i.v. to humans without significant immunologic sequelae (46).

In summary, these experiments demonstrate that peptide radiopharmaceuticals may be specially formulated to enable these molecules to undergo receptor-mediated transport through the BBB. The use of the brain drug delivery approach may allow for imaging brain amyloid or other structures using specific peptide radiopharmaceuticals that are intended to image a specialized function or property of the brain.

\section{Acknowledgments}

This work was supported by the American Health Assistance Foundation, and by National Institutes of Health grant NS-34698.

\section{References}

1. Fischman, A.J., J.W. Babich, and H.W. Strauss. 1993. Peptide radiopharmaceuticals. J. Nucl. Med. 34:2253-2263.

2. Krenning, E.P., D.J. Kwekkeboom, J.C. Reubi, P.M. Van Hagen, C.H.J. van Eijck, H.Y. Oei, and S.W.J. Lamberts. 1992. ${ }^{111}$ In-octreotide scintigraphy in oncology. Metabolism. 41:83-86.

3. Reubi, J.C., L. Kvols, E. Krenning, and S.W.J. Lamberts. 1990. Distribution of somatostatin receptors in normal and tumor tissue. Metabolism. 39:78-81.

4. Haldemann, A.R., H. Roseler, A. Barth, B. Waser, L. Geiger, N. Godoy, R.V. Markwalder, R.W. Seiler, M. Sulzer, and J.C. Reubi. 1995. Somatostatin receptor scintigraphy in central nervous system tumors: role of blood-brain barrier permeability. J. Nucl. Med. 36:403-410.

5. Pardridge, W.M., D. Triguero, J. Yang, and P.A. Cancilla. 1990. Comparison of in vitro and in vivo models of drug transcytosis through the blood-brain barrier. J. Pharmacol. Exp. Ther. 253:884-891.

6. Tomlinson, B.E., G. Blessed, and M. Roth. 1970. Observations on the brains of demented old people. J. Neurol. Sci. 22:205-242.

7. Cummings, B.J., and C.W. Cotman. 1995. Image analysis of $\beta$-amyloid load in Alzheimer's disease and relation to dementia severity. Lancet. 346: 1524-1528.

8. Glenner, G.G., and C.W. Wong. 1984. Alzheimer's disease: initial report of the purification and characterization of a novel cerebrovascular amyloid protein. Biochem. Biophys. Res. Commun. 120:885-890.

9. Masters, C.L., G. Simms, N.A. Weinman, G. Multhaup, B.L. McDonald, and K. Beyruther. 1985. Amyloid plaque core protein in Alzheimer's disease and Down syndrome. Proc. Natl. Acad. Sci. USA 82:4245-4249.

10. Selkoe, D.J., C.R. Abraham, M.B. Podlisny, and L.K. Duffy. 1986. Isolation of low-molecular-weight proteins from amyloid plaque fibers in Alzheimer's disease. J. Neurochem. 46:1820-1834.

11. Pardridge, W.M., H.V. Vinters, J. Yang, J. Eisenberg, T. Choi, W.W. Tourtellotte, V. Huebner, and J.E. Shively. 1987. Amyloid angiopathy of Alzheimer's disease: amino acid composition and partial sequence of a 4200 Dalton peptide isolated from cortical microvessels. J. Neurochem. 49:13941401.

12. Roher, A.E., J.D. Lowenson, S. Clarke, A.S. Woods, R.J. Cotter, E. Gowing, and M.J. Ball. 1993. $\beta$-Amyloid-1(1-42) is a major component of cerebrovascular amyloid deposits: implications for the pathology of Alzheimer disease. Proc. Natl. Acad. Sci. USA. 90:10836-10840.

13. Kang, J., H.G. Lemaire, A. Unterbeck, J.M. Salbaum, C.L. Masters, K.H. Grezeschik, G. Malthaup, K. Beyreuther, and B. Muller-Hill. 1987. The precursor of Alzheimer disease amyloid A4 protein resembles a cell-surface re- 
ceptor. Nature (Lond.). 325:733-736.

14. Stern, R.A., L. Otvos, Jr., J.Q. Trojanowski, and V.M.-Y. Lee. 1989. Monoclonal antibodies to a synthetic peptide homologous with the first 28 amino acids of Alzheimer's disease $\beta$-protein recognize amyloid and diverse glial and neuronal cell types in the central nervous system. Amer. J. Pathol. 134: 973-978.

15. Maggio, J.E., E.R. Stimson, J.R. Ghilardi, C.J. Allen, C.E. Dahl, D.C. Whitcomb, S.R. Vigna, H.V. Vinters, M.E. Labenski, and P.W. Mantyh. 1992. Reversible in vitro growth of Alzheimer disease $\beta$-amyloid plaques by deposition of labeled amyloid peptide. Proc. Natl. Acad. Sci. USA. 89:5462-5466.

16. Saito, Y., J. Buciak, J. Yang, and W.M. Pardridge. 1995. Vector-mediated delivery of [ $\left.{ }^{125} \mathrm{I}\right]$-labeled $\beta$-amyloid peptide $A \beta^{1-40}$ through the blood-brain barrier and binding to Alzheimer disease amyloid of the $\mathrm{A} \beta^{1-40} /$ vector complex. Proc. Natl. Acad. Sci. USA. 92:10227-10231.

17. Walker, L.C., C. Masters, K. Beyreuther, and D.L. Price. 1990. Amyloid in the brains of aged squirrel monkeys. Acta Neuropathol. 80:381-387.

18. Martin, L.J., S.S. Sangram, E.H. Koo, L.C. Cork, T.L. Dellovade, A. Weidemann, K. Beyreuther, C. Masters, and D.L. Price. 1991. Amyloid precursor protein in aged nonhuman primates. Proc. Natl. Acad. Sci. USA. 88:14611465 .

19. Walker, L.C., D.L Price, M.L. Voytko, and D.B. Schenk. 1994. Labeling of cerebral amyloid in vivo with a monoclonal antibody. J. Neuropathol. Exp. Neurol. 53:377-383.

20. Gearing, M., G.W. Rebeck, B.T. Hyman, J. Tiggs, and S.S. Mirra. 1994. Neuropathology and apolipoprotein E profile of aged chimpanzees: implications for Alzheimer disease. Proc. Natl. Acad. Sci. USA. 91:9382-9386.

21. Pardridge, W.M., Y.S. Kang, J.L. Buciak, and J. Yang. 1995. Human insulin receptor monoclonal antibody undergoes high affinity binding to human brain capillaries in vitro and rapid transcytosis through the blood-brain barrier in vivo in the primate. Pharmacol Res. 12:807-816.

22. Swindler, D.R., and J. Erwin, editors. 1986. Comparative Primate Biology. Alan R. Liss, New York.

23. Pardridge, W.M. 1995. Vector-mediated peptide drug delivery to the brain. Advanced Drug Delivery Reviews (Elsevier) 15:109-146.

24. Prigent, S.A., K.K. Stanley, and K. Siddle. 1990. Identification of epitopes on the human insulin receptor reacting with rabbit polyclonal antisera and mouse monoclonal antibodies. J. Biol. Chem. 265:9970-9977.

25. Marsh, J.W. 1988. Antibody-mediated routing of diphtheria toxin in murine cells results in a highly efficacious immunotoxin. J. Biol. Chem. 263: 15993-15999.

26. Riddles, P.W., R.L. Blakeley, and B. Zerner. 1979. Ellman's reagent 5,5'-dithiobis(2-nitrobenzoic acid) — a reexamination. Anal. Biochem. 94:75-81.

27. Pardridge, W.M., R.J. Boado, and Y.S. King. 1995. Vector-mediated delivery of a polyamide ("peptide") nucleic acid analogue through the bloodbrain barrier in vivo. Proc. Natl. Acad. Sci. USA. 92:5592-5596.

28. Yoshikawa, T., and W.M. Pardridge. 1992. Biotin delivery to brain with a covalent conjugate of avidin and a monoclonal antibody to the transferrin receptor. J. Pharmacol. Exp. Ther. 263:897-903.

29. Pardridge, W.M., J. Eisenberg, and J. Yang. 1985. Human blood-brain barrier insulin receptor. J. Neurochem. 44:1771-1778.

30. Bickel, Y., T. Yoshikawa, E.M. Landaw, K.F. Faull, and W.M. Pardridge. 1993. Pharmacologic effects in vivo in brain by vector-mediated peptide drug delivery. Proc. Natl. Acad. Sci. USA. 90:2618-2622.
31. Jefferies, W.A., M.R. Brandon, S.V. Hunt, A.F. Williams, K.C. Gatter, and D.Y. Mason. 1984. Transferrin receptor on endothelium of brain capillaries. Nature (Lond.). 312:162-163.

32. Prior, R., D. D’Urso, R. Frank, I. Prikulis, S. Cleven, R. Ihl, and G. Pavlakovic. 1996. Selective binding of soluble $A \beta 1-40$ and $A \beta 1-42$ to a subset of senile plaques. Am. J. Pathol. 148:1749-1756.

33. Biere, A.L., B. Ostaszewski, E.R. Stimson, B.T. Hyman, J.E. Maggio, and D.J. Selkoe. 1996. Amyloid $\beta$-peptide is transported on lipoproteins and albumin in human plasma. J. Biol. Chem. 271:32916-32922.

34. Rubin, R.H., A.J. Fischman, R.J. Callahan, B.A. Khaw, F. Keech, M. Ahmad, R. Wilkinson, and H.W. Strauss. 1989. ${ }^{111}$ In-labeled nonspecific immunoglobulin scanning in the detection of focal infection. N. Engl. J. Med. 321: 935-940.

35. Zlokovic, B.V., J. Ghiso, J.B. Mackic, J.G. McComb, M.H. Weiss, and B. Frangione. 1993. Blood-brain barrier transport of circulating Alzheimer's amyloid $\beta$. Biochem. Biophys. Res. Commun. 197:1034-1040.

36. Ghersi-Egea, J.F., P.D. Gorevic, J. Ghiso, B. Frangione, C.S. Patlak, and J.D. Fenstermacher. 1996. Fate of cerebrospinal fluid-borne amyloid $\beta$-peptide: rapid clearance into blood and appreciable accumulation by cerebral arteries. $J$. Neurochem. 67:880-883

37. Schlageter, N.L., R.E. Carson, and S.I. Rapoport. 1987. Examination of blood-brain barrier permeability in dementia of the Alzheimer type with $\left[{ }^{68} \mathrm{Ga}\right]$ EDTA and positron emission tomography. J. Cereb. Blood Flow Metabol. 7:1-8.

38. Ghilardi, J.R., M. Catton, E.R. Stimson, S. Rogers, L.C. Walker, J.E. Maggio, and P.W. Mantyh. 1996. Intra-arterial infusion of $\left[{ }^{125} \mathrm{I}\right] \mathrm{A} \beta^{1-40}$ labels amyloid deposits in the aged primate brain in vivo. Neuroreport. 7:2607-2611.

39. Walus, L.R., W.M. Pardridge, R.M. Starzyk, and P.M. Friden. 1996. Enhanced uptake of rsCD4 across the rodent and primate blood-brain barrier following conjugation to anti-transferrin receptor antibodies. J. Pharmacol. Exp. Ther. 277:1067-1075.

40. Jarrett, J.T., and P.T. Lansbury, Jr. 1993. Seeding "one-dimensional crystallization" of amyloid: a pathogenic mechanism in Alzheimer's disease and scrapie? Cell. 73:1055-1058.

41. Kuo, Y.M., M.R. Emmerling, C. Vigo-Pelfrey, T.C. Kasunic, J.B. Kirkpatrick, G.H. Murdoch, M.J. Ball, and A.E. Roher. 1996. Water-soluble A $\beta$ (N40, N-42) oligomers in normal and Alzheimer disease brains. J. Biol. Chem. 271: 4077-4081.

42. Nordstedt, C., J. Naslund, L.O. Tjernberg, A.R. Karlstrom, J. Thyberg, and L. Terenius. 1994. The Alzheimer A $\beta$ peptide develops protease resistance in association with its polymerization into fibrils. J. Biol. Chem. 269:3077330776.

43. Shin, S.U., D. Wu, R. Ramanathan, W.M. Pardridge, and S.L. Morrison. 1997. Functional and pharmacokinetic properties of antibody/avidin fusion proteins. J. Immunol. 158:4797-4804.

44. Winter, G., and C. Milstein. 1991. Man-made antibodies. Nature (Lond.) 349:293-299.

45. Weiner, H.L. 1994. Oral tolerance. Proc. Natl. Acad. Sci. USA. 91: 10762-10765.

46. Samuel, A., G. Paganelli, R. Chiesa, F. Sudati, M. Calvitto, G. Melissano, A. Grossi, and F. Fazio. 1996. Detection of prosthetic vascular and graf infection using avidin/indium-111-biotin scintigraphy. J. Nucl. Med. 37:55-61. 